\title{
Sociodemographic and Clinicopathological Features of Lymphoma Patients in Indonesia: A report from Special Region of Yogyakarta Province
}

\author{
Nungki Anggorowati ${ }^{1,2}$, Indrawati ${ }^{2}$, Amira L. Dhyanti ${ }^{3}$, Hafidh Arkananda ${ }^{3}$, \\ Salsabilla Hasna Rizki ${ }^{3}$, Syahru Agung Setiawan ${ }^{4}$, Miraz Radhea Bagaskoro ${ }^{4}$, \\ Mardiah Suci Hardianti ${ }^{4}$
}

${ }^{1}$ Department of Anatomical Pathology, Faculty of Medicine, Public Health, and Nursing, Universitas Gadjah Mada, Special Region of Yogyakarta, Indonesia. ${ }^{2}$ Anatomical Pathology Laboratory Unit, Integrated Clinical Laboratory, Universitas Gadjah Mada Academic Hospital, Special Region of Yogyakarta, Indonesia. ${ }^{3}$ Faculty of Medicine, Public Health and Nursing, Universitas Gadjah Mada, Special Region of Yogyakarta, Indonesia. ${ }^{4}$ Division of Hematology-Medical Oncology, Department of Internal Medicine, Faculty of Medicine, Public Health and Nursing, Universitas Gadjah Mada, Special Region of Yogyakarta, Indonesia.

\begin{abstract}
Introduction: Lymphoma as a heterogeneous disease has various characteristics not only in the clinical manifestation but also in sociodemographic aspect. Epidemiological data with sociodemographic description in lymphoma is still unexplored. Objective: This study aimed to provide updated and detailed description of lymphoma with emphasis on patient characteristics, sociodemographic data and hematologic findings. Materials and Methods: This was an observational descriptive study with a cross-sectional design. The data were from the medical records in Dr. Sardjito Hospital, a national referral hospital in the Special Region of Yogyakarta Province Indonesia from 2012 to 2018 . All lymphoma patients $>18$ years were included. Patients' characteristics, socio-demographic indicators, tumor characteristic and hematological finding were recorded. The difference of socio-demographic, clinical and laboratory characteristics between Non Hodgkin Lymphoma (NHL) and Hodgkin Lymphoma (HL) was analyzed with Chi-Square, Fisher-Exact, and Mann-Whitney test $(\mathrm{P}<0.05$ was statistically significant). Results: There were 675 cases. Male predominated, mean age at diagnosis was 54.1 for NHL and 42.3 for HL. There was significant difference in the mean of age $(\mathrm{p}=0.000)$, occupation $(\mathrm{P}=0.035)$ and educational level $(\mathrm{P}=0.020)$ between NHL and HL patients. B cell NHL was found to be the most common type of lymphoma, with DLBCL being the most common histopathological type. Hematological findings were found to be within the normal range. Conclusion: There are significant difference in the mean of age, occupation and education level between NHL and HL patients. Further study to explain the scientific reasons of the difference are required.
\end{abstract}

Keywords: lymphoma- NHL-HL- sociodemographic features- clinicopathological features

\section{Introduction}

Lymphoma is a malignant disease of mature lymphocyte in lymphoid tissue generally divided into Non-Hodgkin Lymphoma (NHL) and Hodgkin Lymphoma (HL) [1, 2]. The etiology of lymphoma is still poorly understood, immune system deficiency, infectious agents, exposure to certain organic chemicals (herbicides and pesticides), infection of Epstein-Barr Virus (EBV), immunodeficiency and pharmaceuticals are assumed to contribute to an increased risk of its occurrence [3]. Characteristics of lymphoma may diverse in each patient, but the most of the patients show enlarged lymph nodes, B symptoms (fever, unexplained weight loss, and night sweats), abdominal pain, and enlarged liver or spleen $[4,5]$.

Malignant lymphoma contributes $3.37 \%$ of all cancers 
worldwide. It is more common in developed countries than in developing countries. East Asia region has the lowest incidence rates [3]. NHL as the most common type of lymphoma occurred worldwide is the fifth most common malignancy in adult. B-Cell type accounts for $90 \%$ of all lymphoma cases, and Diffuse Large B-Cell Lymphoma (DLBCL) is the most frequent subtype among NHL [6]. T-cell NHL comprises of approximately $10-15 \%$ of the case [7]. NHLs occurs slightly more in male than in female [8]. Hodgkin Lymphoma cases comprised only about $1 \%$ of all malignancies [4]. It is one of the most common lymphoid malignancies occurring in young adults. Hodgkin's lymphoma exposes bimodal distribution with a first peak in the third decade and a second peak after the age of fifty and men are slightly predominant [9].

In Indonesia, NHL is on the seventh rank of cancers, while HL is on the twenty ninth. In 2018, new cases number of NHL was more than 14.000 cases, while HL accounted for more than 1,000 cases (WHO, 2018). The research conducted by Indonesian Ministry of Health in 2013 showed that the prevalence of lymphoma in Indonesia was $0.06 \%$ with the Special Region of Yogyakarta Province contributing to highest prevalence of $0.25 \%$ with estimation of about 890 patients and West Java constituted the highest estimation of patients at about 2,728 [10]. Frequent characteristics of lymphoma patients in Sanglah hospital, province of Bali from the data of year 2014, showed male gender (76\%), age group of 61 to 76 years old, presence of enlarged lymph nodes (100\%), anemia incidence (72\%), and DLBCL as the most common lymphoma (68\%) [11]. Epidemiological study with sociodemographic description in lymphoma is still rare. Therefore, this study is aimed to provide a detail and updated description about lymphoma including patient characteristics, sociodemographic data and basic hematological data.

\section{Materials and Methods}

\section{Study Population}

This study was an observational descriptive study with a cross-sectional design. The data was procured from the medical records in Dr. Sardjito Hospital Yogyakarta, a national referral hospital in the Special Region of Yogyakarta Province from the year of 2012-2018. All patients with confirmed diagnosis of lymphoma with the age at diagnosis of older than 18 years old were included. Exclusion criteria were unreadable or missing data, or inconclusive pathology result.

Date of birth, sex, ECOG performance status, and nutritional status were withdrawn and indicated as patients' characteristics. Socio-demographic indicators were education, occupation, and address. Occupational status was coded and categorized as follows: unemployed and retired were included in not working population; teacher/lecturer/civil servants in non-medical field, doctor/ nurse/paramedic/healthcare worker, private employee, and student were included in non-manual workers; Indonesian national army/police, farmer/fisherman, laborer were classified into manual workers; entrepreneur/businessman; and others.

We also examined tumor characteristic which consisted of nodal and extranodal site predilection, treatment, histopathological types, and Ann Arbor staging. Hematological finding included hemoglobin level $(\mathrm{Hb})$, leukocyte (neutrophils, lymphocytes, eosinophils, basophils, and monocytes) count, thrombocyte count, LDH levels and ECOG performance status.

\section{Statistical analysis}

Descriptive statistics were used to describe the distribution of patients' characteristic, socio-demographic, tumor status, and hematological finding. Categorical data was presented by frequencies and percentages, while numerical data was presented by means, medians, and standard deviations. The difference of socio-demographic, clinical and laboratory characteristics between NHL and HL was analyzed using Chi-Square, Fisher-Exact, and Mann-Whitney test, with $\mathrm{P}$ value $<0.05$ considered to be statistically significant. All data analysis was done using Statistical Package for Social Sciences (SPSS) version 25. Ethical clearance of this study was issued by the Ethical committee of Faculty of Medicine, Public Health, and Nursing, Universitas Gadjah Mada.

\section{Results}

There were 675 lymphoma patients during the year of 2012-2018. However, not all of the patients had complete data. Therefore, analysis was done based on the data available. Based on the result analysis, it was evident that lymphoma was more common among males $(n=384)$. The mean age at diagnosis was 54.1 years old for NHL and 42.3 years old for HL. Patients mostly came with ECOG performance stage score of $1(n=402)$. The nutritional status of the patients was generally normal $(n=379)$ (Table 1).

Table 1. Characteristics of Lymphoma Patients at Dr. Sardjito Hospital in the Period of 2012-2018

\begin{tabular}{lccc}
\hline Variable (N total) & $\begin{array}{c}\text { NHL } \\
\mathrm{n}(\%)\end{array}$ & $\begin{array}{c}\mathrm{HL} \\
\mathrm{n}(\%)\end{array}$ & P value \\
\hline Sex (675) & & & 0.586 \\
$\quad$ Male (384) & $359(93.5)$ & $25(6.5)$ & \\
Female (291) & $275(94.5)$ & $16(5.5)$ & \\
Age, mean \pm SD & $54.1 \pm 13.6$ & $42.3 \pm 14.0$ & 0 \\
Performance Stage (525) & & & 0.966 \\
$0(52)$ & $48(92.3)$ & $4(3.2)$ & \\
$1(402)$ & $378(94)$ & $24(6)$ & \\
2 (63) & $59(93.7)$ & $4(6.3)$ & \\
$3(4)$ & $4(100)$ & $0(0)$ & \\
$4(1)$ & $1(100)$ & $0(0)$ & \\
Nutritional Status (649) & & & 0.226 \\
Underweight (177) & $169(95.5)$ & $8(4.5)$ & \\
Normal (379) & $356(93.9)$ & $23(6.1)$ & \\
Overweight (83) & $78(94)$ & $5(6)$ & \\
Obese (18) & $15(83.3)$ & $3(16.7)$ & \\
\hline
\end{tabular}


Table 2. Socio-demographic Characteristics of Lymphoma Patients at Dr. Sardjito Hospital in the Period of 2012-2018

\begin{tabular}{|c|c|c|c|}
\hline Variable ( $\mathrm{N}$ total) & $\begin{array}{l}\text { NHL } \\
\text { n (\%) }\end{array}$ & $\begin{array}{c}\mathrm{HL} \\
\mathrm{n}(\%)\end{array}$ & $P$ value \\
\hline Occupation (545) & & & 0.035 \\
\hline Unemployed1 (97) & $92(94.8)$ & $5(5.2)$ & \\
\hline Teacher/Lecturer/civil servants non-medical field ${ }^{2}(58)$ & $53(91.4)$ & $5(8.6)$ & \\
\hline Doctor/Nurse/Paramedic/Healthcare worker ${ }^{2}$ (4) & $4(100)$ & $0(0)$ & \\
\hline Entrepreneur/Businessman (87) & $83(95.4)$ & $4(4.6)$ & \\
\hline Indonesian National Army/Police ${ }^{3}$ (4) & $3(100)$ & $0(0)$ & \\
\hline Private Employee $^{2}(50)$ & $47(94)$ & $3(6)$ & \\
\hline Student $^{2}(11)$ & $8(72.7)$ & $3(27.3)$ & \\
\hline Farmer/Fisherman $^{3}(101)$ & $97(96)$ & $4(4)$ & \\
\hline Laborer $^{3}(73)$ & $73(100)$ & $0(0)$ & \\
\hline Retired $^{1}(54)$ & $54(100)$ & $0(0)$ & \\
\hline Others (6) & $5(83.3)$ & $1(16.7)$ & \\
\hline Education (422) & & & 0.02 \\
\hline No Formal Education (3) & $3(100)$ & $0(0)$ & \\
\hline Elementary (169) & $164(97)$ & $5(3)$ & \\
\hline Junior High (58) & $58(100)$ & $0(0)$ & \\
\hline Senior High (132) & $122(92.4)$ & $10(5.9)$ & \\
\hline Diploma (20) & $19(95)$ & $1(5)$ & \\
\hline Undergraduate (34) & $33(97.1)$ & $1(2.9)$ & \\
\hline Post-graduate (6) & $4(66.7)$ & $2(33.3)$ & \\
\hline Address (675) & & & 0.564 \\
\hline \multicolumn{4}{|l|}{ Yogyakarta Special Region Province (287) } \\
\hline Sleman district (104) & $96(92.3)$ & $8(7.7)$ & \\
\hline Yogyakarta municipality (32) & $29(90.6)$ & $3(9.4)$ & \\
\hline Bantul district (68) & $65(95.6)$ & $3(4.4)$ & \\
\hline Gunung Kidul dictrict (41) & $38(92.7)$ & $3(7.3)$ & \\
\hline Kulon Progo district (42) & $38(90.5)$ & $4(9.5)$ & \\
\hline Outside the Province (388) & $368(94.8)$ & $20(5.2)$ & \\
\hline
\end{tabular}

${ }^{1}$ Not working; ${ }^{2}$ Non-manual workers; ${ }^{3}$ Manual worker

Patients' occupation were mostly farmer or fisherman $(n=101)$ followed by entrepreneur or businessman $(n=87)$. Based on their educational level, most patients had finished elementary school $(n=169)$ followed by senior high school $(\mathrm{n}=132)$. Most patients who seek treatment at Dr. Sardjito Hospital were actually from outside the province of Yogyakarta Special Region-which consisted of 4 districts and 1 municipality $(\mathrm{n}=388)$ (Table 2 ).

Differences in patient characteristics by lymphoma classification of NHL and HL were also provided in Table 1. There was a statistically significant difference between the means of age among NHL and HL population $(\mathrm{P}=<0.000)$.

Our study also revealed a correlation between sociodemographic characteristics with NHL or HL patients. As shown in Table 2, there were significant differences among different occupation groups and in terms of education level in regard to classification of lymphoma $(\mathrm{P}=0.035$ and $\mathrm{P}=0.020$, respectively).

This study found that NHL B-Cell was the most prevalent lymphoma type. It accounted for $61.9 \%$ or 418 cases. Moreover, there were 201 cases of DLBCL observed $(29.8 \%)$ which made DLBCL as the most frequent subtype of lymphoma. It was followed by Classical Hodgkin Lymphoma, Nodular Sclerosing subtype (18 cases, 2.7\%) and Follicular Lymphoma (16 cases, 2.4\%) (Table 3).

Based on nodal involvement, this study found that most of the patient $(37.8 \%)$ had single nodal. The three most common sites of nodal predilection were in cervical (43\%), followed by Waldeyer's ring (13.8\%) and axillary $(11.5 \%)$. For the extranodal involvement, $42.2 \%$ of the patients showed to have single extranodal with the 3 most frequent sites of predilection were head and neck (14.2\%), nose and paranasal sinuses $(12.8 \%)$, and spleen in HL cases $(3.5 \%)$. There were $45.1 \%$ patients with Ann Arbor stage I disease (Table 4). The hematologic characteristic of the patients was found to be within the normal range (Table 5). 
Table 3. Lymphoma Histopathology Type

\begin{tabular}{|c|c|}
\hline Variable ( $\mathrm{N}$ total) & $\mathrm{N}(\%)$ \\
\hline \multicolumn{2}{|l|}{ Lymphoma Classification (675) } \\
\hline NHL B-Cell & $418(61.9)$ \\
\hline NHL T-cell & $58(8.6)$ \\
\hline Hodgkin's Lymphoma & $41(6.1)$ \\
\hline NHL NOS & $158(23.4)$ \\
\hline \multicolumn{2}{|l|}{ Lymphoma Subtypes (675) } \\
\hline \multicolumn{2}{|l|}{ NHL B-Cell } \\
\hline DLBCL & $201(29.8)$ \\
\hline NHL B-Cell, NOS & $160(23.7)$ \\
\hline Follicular Lymphoma & $16(2.4)$ \\
\hline $\begin{array}{l}\text { T-Cell/Histiocyte-rich Large } \\
\text { B-Cell Lymphoma }\end{array}$ & $15(2.2)$ \\
\hline Small Lymphocytic Lymphoma & $12(1.8)$ \\
\hline Burkitt Lymphoma & $5(0.7)$ \\
\hline Lymphoma MALT-type & $4(0.6)$ \\
\hline Primary Mediastinal B-Cell Lymphoma & $3(0.4)$ \\
\hline $\begin{array}{l}\text { Extranodal Marginal Zone } \\
\text { B-cell Lymphoma }\end{array}$ & $1(0.1)$ \\
\hline Extraosseous Plasmacytoma & $1(0.1)$ \\
\hline \multicolumn{2}{|l|}{ NHL T-Cell } \\
\hline NHL T cell, NOS & $37(5.5)$ \\
\hline $\begin{array}{l}\text { Extranodal NK-/T-cell lymphoma, nasal } \\
\text { type }\end{array}$ & $11(1.6)$ \\
\hline Anaplastic Large Cell Lymphoma & $7(1.0)$ \\
\hline Cutaneous T-Cell Lymphoma & $2(0.3)$ \\
\hline Angioimmunoblastic T-Cell Lymphoma & $1(0.1)$ \\
\hline \multicolumn{2}{|l|}{ HL } \\
\hline $\begin{array}{l}\text { Classical Hodgkin Lymphoma, } \\
\text { Nodular Sclerosing }\end{array}$ & $18(2.7)$ \\
\hline Hodgkin Lymphoma, NOS & $9(1.3)$ \\
\hline $\begin{array}{l}\text { Classical Hodgkin Lymphoma, } \\
\text { Mixed Cellularity }\end{array}$ & $7(1.0)$ \\
\hline $\begin{array}{l}\text { Classical Hodgkin Lymphoma, } \\
\text { Lymphocyte-rich }\end{array}$ & $3(0.4)$ \\
\hline $\begin{array}{l}\text { Classical Hodgkin Lymphoma, } \\
\text { Lymphocyte-depleted }\end{array}$ & $2(0.3)$ \\
\hline Classical Hodgkin Lymphoma & $1(0.1)$ \\
\hline $\begin{array}{l}\text { Nodular Lymphocyte Predominant } \\
\text { Hodgkin Lymphoma }\end{array}$ & $1(0.1)$ \\
\hline NHL, NOS & $158(23.4)$ \\
\hline
\end{tabular}

\section{Discussion}

Our study found that lymphoma patients in Dr. Sardjito hospital was mostly male $(\mathrm{n}=384)$. This male predominance could also be found in numerous studies, including a study in 2020 conducted in Chinese population [12] and a multicenter study of NHL in developing country in 2016 [13]. Regarding age, there was a significant difference in the mean of age between NHL and HL population $(p=<0.000)$. This study found the mean of age for NHL and HL were $54.1 \pm 13.6$ years and $42.3 \pm 14.0$ years respectively. In other study conducted in Sudan in 2020 found that the mean age of HL was $47.14 \pm 22.31$ years and NHL was $40.22 \pm 24.62$ years [14].

The nutritional status of the patients was mostly normal $(n=379)$. The nutritional status of overweight and obese are associated to a worse prognosis and lower quality of life in lymphoma patients. There is further

Table 4. Tumor Characteristics

\begin{tabular}{|c|c|}
\hline Variable ( $\mathrm{N}$ total) & $\mathrm{N}(\%)$ \\
\hline \multicolumn{2}{|l|}{ Single/ Multiple Nodal (474) } \\
\hline No Tumor & $211(30.8)$ \\
\hline Single & $259(37.8)$ \\
\hline Multiple & $215(31.4)$ \\
\hline \multicolumn{2}{|l|}{ Single/Multiple Extranodal (357) } \\
\hline No Tumor & $300(45.7)$ \\
\hline Single & $277(42.2)$ \\
\hline Multiple & $80(12.2)$ \\
\hline \multicolumn{2}{|l|}{ Nodal Predilection (474) } \\
\hline Axillary & $79(11.5)$ \\
\hline Cervical & $296(43.0)$ \\
\hline Inguinal \& Femoral & $122(17.7)$ \\
\hline Intra-abdominal & $21(3.1)$ \\
\hline Intrathoracic & $3(0.4)$ \\
\hline Mediastinal & $20(2.9)$ \\
\hline Mesenteric & $26(3.8)$ \\
\hline Paraaortic & $61(8.9)$ \\
\hline Pelvic & $25(3.6)$ \\
\hline Retroperitoneal & $3(0.4)$ \\
\hline Spleen (HL) & $8(1.2)$ \\
\hline Supraclavicular & $17(2.5)$ \\
\hline Waldeyer's ring & $95(13.8)$ \\
\hline \multicolumn{2}{|l|}{ Extranodal Predilection (357) } \\
\hline Bone & $23(3.3)$ \\
\hline $\mathrm{CNS}$ & $2(0.3)$ \\
\hline Musculocutaneous & $20(2.9)$ \\
\hline Gaster & $2(0.3)$ \\
\hline Genital & $17(2.5)$ \\
\hline Head and neck & $98(14.2)$ \\
\hline Intestinum & $37(5.4)$ \\
\hline Retroperitoneal & $36(5.2)$ \\
\hline Liver & $15(2.2)$ \\
\hline Mammary & $12(1.7)$ \\
\hline Nose and paranasal sinuses & $88(12.8)$ \\
\hline Pulmo & $22(3.2)$ \\
\hline Spleen (NHL) & $24(3.5)$ \\
\hline Thorax & $10(1.5)$ \\
\hline \multicolumn{2}{|l|}{ Ann Arbor Stage (517) } \\
\hline I & $233(45.1)$ \\
\hline II & $154(29.8)$ \\
\hline III & $79(15.3)$ \\
\hline IV & $51(9.9)$ \\
\hline
\end{tabular}


Table 5. Hematologic Findings

\begin{tabular}{lcc}
\hline Variable & Mean & SD \\
\hline Hemoglobin & $12.3 \mathrm{mg} / \mathrm{dL}$ & 1.9 \\
Platelet count & 329.2 cells $/ \mu \mathrm{L}$ & 263.7 \\
WBC count & $10.1 \times 10^{3}$ cells $/ \mu \mathrm{L}$ & 13.2 \\
Differential WBC count & $8.5 \times 10^{3}$ cells $/ \mu \mathrm{L}$ & 43.5 \\
Segmented Neutrophils & & \\
Band Neutrophils & $0.8 \times 10^{3}$ cells $/ \mu \mathrm{L}$ & 2.5 \\
Lymphocytes & $3.2 \times 10^{3}$ cells $/ \mu \mathrm{L}$ & 14 \\
Monocytes & $1.0 \times 10^{3}$ cells $/ \mu \mathrm{L}$ & 4.2 \\
Eosinophils & $0.3 \times 10^{3}$ cells $/ \mu \mathrm{L}$ & 0.4 \\
Basophils & $0.1 \times 10^{3}$ cells $/ \mu \mathrm{L}$ & 0.5 \\
\hline
\end{tabular}

dysregulation in iron metabolism in overweight and obesity patient which could lead to the presence of anemia. Furthermore, pro-inflammatory cytokines - such as IL-6 and IL-1 - are also increased due to presence of excess adipose tissue, worsening the systemic inflammation caused by the malignancy itself [15]. Hence, the normal and underweight status of the patients is considered a protective factor.

The most prevalent occupation was found to be farmer/fisherman $(n=101)$. There had been evidence that exposure to chemicals used as herbicides and pesticides - namely organochlorine, organophosphate, and phenoxyl acid compounds - are considered to increase the risk of developing lymphoma [16]. There were significant differences among different occupation and the lymphoma classification $(p=0.035)$. It is supported by a study conducted in Iran in 2012 to 150 lymphoma cases admitted to two reference university hospitals in Tehran that they found a significant difference between patients' occupation and lymphoma classification in Tehran. Some occupations may cause increase in NHL risks such as farming, textile industry, metal working, veterinaries, rubber industry, and benzene exposure [17].

Regarding the education level, there was statistically significant difference between HL and NHL $(p=0.020)$. This finding went against the findings of a European multicenter study that was conducted in 2010 which stated no consistent association between education and the overall risk of HL or NHL [18]. However, the same study also stated that there was positive correlation between educational level and risk of B cell chronic lymphocytic leukemia (B-CLL) in women. The risk of DLBCL was found to be significantly lower in patient with university degree compared to those of lower educational level.

This study found that $61.9 \%$ of all patients were diagnosed with B-Cell NHL and 29.8\% were DLBCL. This is similar to a study from Sanglah Hospital, Province of Bali in Indonesia in 2015 [19]. Based on the Ann Arbor Stage, about $45.1 \%$ of all patients in this study had stage I. This is in contrary with two studies that stated that the largest number of proportions with Ann Arbor stage was stage IV $[17,18]$. Regarding to nodal site involvement, we found the majority of the cases were with single site $(37.8 \%)$ and the most affected location was cervical region $(43 \%)$. This finding is similar with a study conducted in
French where the majority were single tumor $(42.2 \%)$ with cervical lymph nodes $(36.8 \%)$ as the most common site [20]. Our study also found extranodal involvement in $54.4 \%$ patients, mostly with single involvement with most predilection of head and neck area (14.2\%) followed by nose and paranasal sinuses area $(12.8 \%)$. Other study conducted in the province of Jakarta-Indonesia also stated the same finding where 50 cases $(100 \%)$ showed to have $\leq 1$ extranodal involvement and neck as the most common area (86 cases, 54.1\%) [21].

The basic hematological finding of hemoglobin, white blood cell count, and platelet count were found to be within the normal range with the respective mean of $12.3 \mathrm{mg} / \mathrm{dl}$, $10.1 \times 10^{3}$ cells $/ \mu \mathrm{L}$, and 329.2 cells $/ \mu \mathrm{L}$. Similar result was reported from Sanglah Hospital Bali [19]. Aberrations in blood examination typically occur when there was bone marrow involvement. Therefore, it could be concluded that most patient did not come with bone marrow involvement. Our data showed that patient who initially diagnosed with bone extranodal tumor was only $3.3 \%$.

There are several limitations of this study. The retrospective design of the study only permitted us to work with the existing data with no possibility of tracing the patients to complete the unavailable data. The study was also done in a single center which may not be able to reflect the real condition of the population.

In conclusion, We retrieved 675 data from Dr. Sardjito Hospital in Yogyakarta Special Region Province Indonesia from the year of 2012-2018. We found out that lymphoma was more frequent in male patients, with the mean age of 54.1 years old in NHL and 42.3 years old in HL. DLBCL was found to be the most common histopathological type of lymphoma. Sociodemographic analysis revealed the statistically significant difference in the occupation and education level of NHL and HL patients. The difference in mean age of NHL and HL patients was also found to be statistically significant. Further study should be done to analyze in order to further explain the scientific reasons behind significance of occupation and education to the risk of lymphoma.

\section{Acknowledgements}

This study was funded by Hibah Dana Masyarakat (DAMAS) Research, Faculty of Medicine, Public Health and Nursing, Universitas Gajdah Mada. Authors declared no conflict of interest.

\section{References}

1. Nair R, Kakroo A, Bapna A, Gogia A, Vora A, Pathak A, Korula A, Chakrapani A, Doval D, Prakash G, Biswas G, Menon H, Bhattacharya M, Chandy M, Parihar M, Vamshi Krishna M, Arora N, Gadhyalpatil N, Malhotra P, Narayanan P, Nair R, Basu R, Shah S, Bhave S, Bondarde S, Bhartiya S, Nityanand S, Gujral S, Tilak TVS, Radhakrishnan V. Management of Lymphomas: Consensus Document 2018 by an Indian Expert Group. Indian Journal of Hematology \& Blood Transfusion: An Official Journal of Indian Society of Hematology and Blood Transfusion. 2018 07;34(3):398-421. https://doi.org/10.1007/s12288-018-0991-4 
2. Caron A A, Jacobson, Longo D. Harrison's Principles of Internal Medicine. 20th ed. Chapter 104: Non-Hodgkin's Lymphoma. McGraw Hill; 2018.

3. Huh J. Epidemiologic overview of malignant lymphoma. The Korean Journal of Hematology. 2012 06;47(2):92-104. https://doi.org/10.5045/kjh.2012.47.2.92

4. Gobbi P, Ferreri A, Ponzoni M, Levis A. Hodgkin lymphoma. Crit Rev Oncol Hematol. 2013;85(2):216-37.

5. Martin P. Understanding Non-Hodgkin Lymphoma (Lymphoid Neoplasms) [Internet]. Lymphoma.org. 2020 [cited 17 November 2020]. Available from: https://ymphoma.org/wp.

6. Najafi S, Payandeh M, Sadeghi M. Clinicopathology Figures and Survival of Non-Hodgkin's Lymphoma in Iran. Iranian Journal of Cancer Prevention. 201701 31;10(1). https://doi. org/10.17795/ijcp-5226

7. Phan A, Veldman R, Lechowicz MJ. T-cell Lymphoma Epidemiology: the Known and Unknown. Current Hematologic Malignancy Reports. 2016 Dec;11(6):492-503. https://doi.org/10.1007/s11899-016-0353-y

8. Bray F, Ferlay J, Soerjomataram I, Siegel RL, Torre LA, Jemal A. Global cancer statistics 2018: GLOBOCAN estimates of incidence and mortality worldwide for 36 cancers in 185 countries. CA: a cancer journal for clinicians. 2018 Nov;68(6):394-424. https://doi.org/10.3322/caac.21492

9. Mozaheb Z. Epidemiology of hodgkin's lymphoma. Health (N Y). 2013;05(05):17-2.

10. Kementerian Kesehatan R. Data dan Kondisi Penyakit Limfoma di Indonesia [Internet]. Pusat Data dan Informasi Kementerian Kesehatan RI. 2015 [cited 17 November 2020]. Available from: https://pusdatin.kemkes.go.id/resources/ download/pusdatin/infodatin/infodatin-limfoma.pdf.

11. Suryadiarsa I, Rena N, Dharmayuda T. Tingkat Harapan Hidup Pasien Limfoma Non-Hodgkin Berdasarkan Skor Ipi Yang Mendapatkan Kemoterapi Lini Pertama Di Rsup Sanglah Denpasar Tahun 2014. E-J Med Udayana [Internet]. 2019 May 14 [cited 2020 Nov 3];8(5). Available from: https://ojs.unud.ac.id/index.php/eum/article/view/51656.

12. Liu W, Ji X, Song Y, Wang X, Zheng W, Lin N, Tu M, Xie Y, Ping L, Ying Z, Zhang C, Deng L, Wu M, Feng F, Leng X, Sun Y, Du T, Zhu J. Improving survival of 3760 patients with lymphoma: Experience of an academic center over two decades. Cancer Medicine. 202004 12;9(11):3765-3774. https://doi.org/10.1002/cam4.3037

13. Perry AM, Diebold J, Nathwani BN, MacLennan KA, Müller-Hermelink HK, Bast M, Boilesen E, Armitage JO, Weisenburger DD. Non-Hodgkin lymphoma in the developing world: review of 4539 cases from the International Non-Hodgkin Lymphoma Classification Project. Haematologica. 2016 Oct;101(10):1244-1250. https://doi.org/10.3324/haematol.2016.148809

14. Abdalhabib EK. Relative Frequencies and Patterns of Malignant Lymphoma in a Reference Centre in Khartoum, Sudan: A Descriptive Study Based on the WHO Classification of Lymphoid Neoplasms. Asian Pacific Journal of Cancer Care. 202007 08;5(2):107-112. https://doi.org/10.31557/ apjcc.2020.5.2.107-112

15. Aigner E, Feldman A, Datz C. Obesity as an emerging risk factor for iron deficiency. Nutrients. 201409 11;6(9):35873600. https://doi.org/10.3390/nu6093587

16. Bassey E. Non-Hodgkin's Lymphoma [Internet]. Interventions in Pediatric Dentistry: Open Access Journal. 2018 [cited 2020 Mar 15]. Available from: https://lupinepublishers. com/index.php.

17. Aminian O, Abedi A, Chavoshi F, Ghasemi M, RahmatiNajarkolaei F. Evaluation of Occupational Risk Factors in Non-Hodgkin Lymphoma and Hodgkin's Disease in Iranian
Men. Iran J Cancer Prev. 2012;5(4):189-93.

18. Hermann S, Rohrmann S, Linseisen J, Nieters A, Khan A, Gallo V, et al. Level of education and the risk of lymphoma in the European prospective investigation into cancer and nutrition. J Cancer Res Clin Oncol. 2010;136(1):71-7.

19. Paramartha I, Rena R. Karakteristik Pasien Limfoma Maligna Di Rsup Sanglah Tahun 2015. 6. 2017;9.

20. Laurent C, Do C, Gourraud P, Paiva GR, Valmary S, Brousset P. Prevalence of Common Non-Hodgkin Lymphomas and Subtypes of Hodgkin Lymphoma by Nodal Site of Involvement: A Systematic Retrospective Review of 938 Cases. Medicine. 2015 06;94(25):e987. https://doi. org/10.1097/MD.0000000000000987

21. Reksodiputro A. Multicentre Epidemiology and Survival Study of B Cell Non Hodgkin Lymphoma Patients In Indonesia. Journal of Blood Disorders \& Transfusion. 2015 01 01;06. https://doi.org/10.4172/2155-9864.1000257

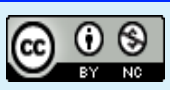

This work is licensed under a Creative Commons AttributionNon Commercial 4.0 International License. 